Г. Поллок позволяет предположить, что ведущей в ее творчестве является идеологическая установка, а не исследовательская позиция. Концепция Г. Поллок основывается на трактовке женского или мужского начала в творчестве художника как гендерных категориях, а также господствующих в обществе социальных ролях и стереотипах.

Ключевые слова: Гризельда Поллок, феминистическое искусствоведение, феминистическая критика искусства.

Olena Zarytska, PhD of Philosophical Sciences, Assist.

Taras Shevchenko National University of Kyiv, Kyiv, Ukraine

\title{
FEMINIST ART GRIZELDY POLLOK AS A CHALLENGE TO THE ART OF THE PAST
}

The theoretical work of one of the founders and leading figures of modern feminist art Griselda Pollock is considered. Representing researchers whose ideas were shaped by the radical cultural and social revolution of the 1960s and 1970s, she belongs to the second generation of feminist art criticism. The author points to the eclectic methodological position of G. Pollock, which combines a number of areas associated with its "radicalism" in relation to the classical areas of art history and social thought. In particular, it is Marxism, poststructuralism of R. Bart and M. Foucault, Freudian psychoanalysis etc. Methodological eclecticism G. Pollock suggests that the leading in her work is her ideological attitude, rather than research position. Although G. Pollock's theoretical constructions are formally based on specific biographical and art studies of artists of the past, methodological eclecticism does not allow to characterize them as scientific or at least consistently logical in their construction. The author concludes that substantively, the concept of G. Pollock is based on the interpretation of female (and male) principles in the artist's work as a gender category, defined by the prevailing social roles and stereotypes in society. G. Pollock uses the concept of "bourgeoisie" in relation to the culture of the masculine society of the past; attempts to develop the concept of "death of the author" by R. Bart in the interpretation of the socially determined figure of the artist (on the example of W. Van Gogh); quite arbitrarily uses the apparatus of Freudian psychoanalysis to read ("deconstruct") works of art, in particular, paintings by W. Van Gogh and A. de Toulouse-Lautrec. Thus, G. Pollock turns feminist art criticism into an ideological platform for the development of a range of ideological and theoretical currents, united by their radicalism and opposition to classical art and the ideological foundations of modern civilization as a whole.

Keywords: Griselda Pollock, feminist art history, feminist critique of art.

УДК 32.019 .51

DOI: $10.17721 /$ sophia.2021.17.9

В. Ю. Омельченко, канд. філос. наук, асист. Київський національний університет імені Тараса Шевченка, Київ, Україна ORCID: 0000-0001-7589-7834 e-mail: victoria.007.omelchenko@gmail.com

\section{ДО ПИТАННЯ ПРО СУЧАСНІ МІФИ. ПОЛІТИЧНИЙ МІФ ЯК ПРИКЛАДНА МІФОЛОГІЯ}

Присвячено дослідженню поняття "міфу" та виявленню сутнісних ознак "політичного міфу", з'ясуванню та проясненню питання, чим є "політичний міф" сьогодення, якою мовою він говорить, до чого апелює. Доведено, що "політичний міф" є комунікативною системою, яка деформує реальність. Встановлено, що кожен "політичний міф" має свій строк придатності і межі своєї інтерпретації. Підтверджено, що "політичний міф" є одним із найефективніших інструментів для задоволення таких політичних цілей, як досягнення влади та ї̈ легітимація. Завдяки дослідженню специфічних ознак "політичного міфу" вдалося виявити, що політичний дискурс є ірраціональним, а політичні промови апелюють до аргументу чуттєвого, а не раціонального. "Політичний міф" моделює свою "картину світу", яка є спрощеною, самозрозумілою, самоочевидною. Обгрунтовано, що здатність критичного судження, уміння працювати з інформацією та якісна аналітика з вуст незаангажованих 3МІ та експертного середовища, хоч і не є панацеєю, але все ж таки частково нівелює "силу" "політичного міфу". Окрім цього, виявлено роль і значення таких понять, як "політична магія" та "політичний спектакль" у контексті "політичної міфології" як прикладної міфології.

Ключові слова: міф, політичний міф, політтехнології, електорат, політичні цілі, "теорія змови", "політична магія", "політичний спектакль".

"Благо цілого вимагає саможертовності окремого", Ф. Ніцше

Ніщо так не приваблює людей, як жага до влади, саме "воля до влади" (Ф. Ніцше) продукує застосування перевірених часом і емпіричним досвідом інструментів політтехнологій, одним із яких $є$ політичний міф. Політичний міф реанімує наші первісні почуття, апелює до інстинктів, деформує реальність.

Проблема міфру $є$ досить масштабною і вивчається $з$ різних позицій і за посередництва різних методологій. Розмаїття аспектів міфу розглядається у сферах генеалогії міфу, релігієзнавства, психоаналізу, медіа, реклами, піару, маркетингу тощо. У межах цієї статті нас цікавить сутність міфу в її сучасному контексті прочитання. Об'єктом нашої розвідки є поняття міфу взагалі, а предметом - сутнісні ознаки політичного міфу.

Як теоретичною основою та джерелознавчим фундаментом ми послуговуватимемось роботами О. Лосєва [8], А. Цуладзе [13], Г. Лебона [5], Е. Касірера [4], М. Едельмана (Murray Edelman) [16], Г. Тюдора (Henry Tudor) [17], Р. Барта [2] та ін. У вітчизняному контексті вивчення політичного міфу розглядається у таких аспектах, як політичний інструмент і політична реальність (Ю. Шайгородський [14]), як знаряддя впливу на електоральні вподобання (Д. Мадрига [9]), як засіб впливу на індивідуальну та масову свідомість (О. Березовська-Чміль та Т. Черниш [3], С. Матвієнків та В. Штерн [10]) поряд із вивченням ролі міфу в контексті відродження національної свідомості українського народу (Ю. Левенець [6]).

Відповідно, досліджуючи цю тему, ми будемо рухатись від "загального до конкретного" (мовою Г. Гегеля), від поняття "міфу" взагалі до поняття "політичного міфу" зокрема. Розпочнемо $з$ подолання передсудів, згідно 3 якими визначення "міфу" трактують як загадкову оповідь первісних людей, а сам "міф" розглядається як такий, що передує науковому сприйняттю світу. На противагу такому визначенню, ми пропонуємо визначати "міф" як спосіб пояснення світу, а "політичний міф" - як штучно створену "реальність", обумовлену жагою до влади, що досягається засобом впливу на масову свідомість.

Звернемось до альфи і омеги дослідження міфології, а саме - дослідження О. Лосєва (1893-1988), фрілоcoфра, перекладача, історика, фрілолога, автора таких робіт, як "Філософрія імені", "Діалектика художньої форми", "Історія античної естетики" та "Діалектика міфу", яку ми й осмислюємо в межах цього дослідження. Оле- 
ксій Лосєв застерігає нас від упередженого сприйняття міфу як вигадки, ілюзії, франтазії, яка властива виключно первісній людині. Такий "обмежений" і "спрощений" погляд на міф зумовлений тим, що ми схильні оцінювати його з позиції науки. Пригадаємо, Н. Гудмен мовив про небезпеку "заангажованого ока", яке є упередженим на предметі свого дослідження, що перешкоджає на шляху до досягнення "розуміння" (у сенсі герменевтики). Таким чином, О. Лосєв і застерігає нас від такого легковажного сприйняття міфу "заангажованими очима".

За О. Лосєвим, міф не $є$ вигадкою, а є самою дійсністю, "категорією думки і життя", відповідно, міф позбавлений усього довільного і вигаданого. Крім того, міф не $€$ хаотичним і ілюзорним, він має свою лаконічну структуру і є логічним, себто є "діалектично необхідною категорією свідомості і буття взагалі" [8]. Тобто міф не $є$ ані ідеальним буттям, ані вигаданим, а є смисловим буттям. Міф нічого не вигадує, а $є$ комунікативною практикою сприйняття, інтерпретації та пояснення довколишнього світу. Відповідно, О. Лосєв констатує, що міф не $є$ примітивно-науковою химерою, а $є$ "живим суб'єктоб'єктним взаємообміном, що містить свою власну, позанаукову істинність, правдивість, закономірність і структуру", тобто міф - це завжди історія про реальне, живе і безпосереднє [8]. Такими є риси міфру, за О. Лосєвим.

У свою чергу, Р. Барт (1915-1980), фрілософ, теоретик семіотики, науки про знаки і символи) також досліджує міфи, але розглядає їх з погляду семіології. Якими ж є риси міфру, за Р. Бартом? Міф - це:

- по-перше, комунікативна система;

- по-друге, міфи нічого не приховують, не є істиною або хибою, навпаки, вони спотворюють та деформують реальність;

- по-третє, міфи мають свій строк придатності, це означає, що архаїчні міфи можуть бути і $\epsilon$, але вічних міфрів немає;

- по-четверте, міф містить дві семіологічні системи: мову - об'єкт та метамову;

- по-п'яте, міф має смисл, форму і значення. Міф одночасно позначає, повідомляє, переконує, приписує;

- по-шосте, міф має імперативний та спонукальний характер, він апелює до конкретного реципієнта [2].

Такими є риси міфу за Р. Бартом. Також дослідник наголошує на необхідності врахування особливостей прочитання та розшифрування міфрів. Отже, є три способи прочитання міфу. Перший з них є буквальним, тобто таким, що фокусується на формі міфу. Другий передбачає вміння розрізняти смисл та фрорму. Саме такий критичний підхід дозволяє зрозуміти міф і побачити його "слабкі місця". Третій спосіб є споживацьким, тобто некритичним, що передбачає його сприйняття у єдності смислу і форми, що створює ефект подвійного впливу міфу і характеризує споживацьке, некритичне сприйняття [2]. Таке споживацьке та "сліпе" сприйняття міфу відповідає меті його створення. 3 заявлених Р. Бартом трьох способів "прочитання" міфу лише два перших способи $€$ рефлексивними та аналітичними i дозволяють як виявляти, так і руйнувати міфи. Р. Барт пропонує до нашої уваги "прочитання" міфу в таких контекстах сучасності, як реклама, маркетинг, ЗМІ, які тиражують інформацію і здатні до маніпуляцій. Ознайомившись із таким трактуванням міфів у концепції Р. Барта, ми дійшли таких попередніх висновків. Р. Барт, на відміну, від О. Лосєва, досліджує не архаїчні, а сучасні міфи. Ті міфи, які штучно створюються, мають свою мету і термін призначення. Це міфи, які покликані привертати увагу, сприяти збільшенню продажів, ті, які $€$ характерними і поширеними для "суспільств споживання". Зокрема, різновид таких сучасних міфрів є у сорері реклами. Оскільки ми попередньо вжили поняття "суспільство споживання", то вважаємо за необхідне згадати Е. Фромма, який написав роботу "Мати чи бути?", в межах якої сформулював два антагоністичні принципи "мати" i "бути", перший з яких позначає споживання, забезпечення виключно матеріальних потреб і запитів та некритичне сприйняття, а другий - якісний показник, що передбачає вміння цінувати необхідне, критично сприймати інформацію та орієнтуватися на внутрішні чесноти та цінності.

Зрештою, Р. Барт переконливо доводить, що "міф" "діє економно, знищує нанівець складність людських вчинків, надає їм простоти сутностей", "міф" створює світ без протиріч. "Міф" спрощує світ, зводить його до простих алгоритмів, а в такому "зручному" світі втрачається звичка послуговуватись здатністю критичного мислення. Міф - це завжди "історія", тобто міф пояснює світ спрощеною мовою. Таким чином, сучасний міф комфортно "почуває" себе у сферах масмедіа, рекламі та політиці. Відповідно до короткострокової мети кожного з таких міфів здійснюється описання світу, створюється ілюзія, такий собі "симулякр" (мовою Ж. Бодріяра), завдяки якому і досягається мета.

Від поняття "міфу" в інтерпретаціях О. Лосєва та Р. Барта перейдемо до визначення сутнісних ознак ще одного різновиду сучасних міфів - "політичного міфу". Ознайомившись 3 різними підходами до визначення останнього, ми приймаємо як аксіому положення, згідно з яким "політичний міф" створюється в лабораторних умовах для відповідних політичних цілей, якими є боротьба за владу ("воля до влади" Ф. Ніцше), легітимація влади, досягнення політичного домінування. Відповідно, ідеться про міфи, які створюються і використовуються у контексті політичної боротьби.

Одним із перших, хто запропонував використовувати міф як політичний інструмент, був Ж. Сорель (1847-1922), французький фрілософ і соціолог, який вважав, що "міфи мають створюватись штучно, аби надихати маси" [11]. Ж. Сорель протиставив міф як утопії, так і ідеології. Сутнісною ознакою міфру $є$ орієнтація на теперішнє, а не минуле чи майбутнє. Міф - це теперішнє, це момент "тут і зараз", це монолог, що виголошується 3 визначеною метою. У свою чергу, Г. Тюдор [17] визначив міф як "ідеологічно марковану оповідь", яка має за мету створити "свій світ", свою "правду" про минуле та теперішнє. Власне, схильність створювати міфи як засіб впливу на Інших і $€$ ознакою сучасного світу. Міф - це драматична конструкція, що вступає у боротьбу з реальністю.

О. Сурков у статті "Міф, сила і насилля в фрілософіії Ж. Сореля" [11] підкреслив, що міф - це "сукупність образів, які здатні інстинктивно викликати в людей необхідні почуття для досягнення тих чи інших дій. Міф слід розглядати поряд з утопією і ідеологією. О. Сурков пояснює міф словами Р. Барта, тобто трактує останній як "подвійну семіологічну систему". Міф використовує слова "буденної мови, позбавляючи їх смислу і наділяючи новим, більш функкціональним, придатним для політичного використання". Наприклад, К. Леві-Стросс ототожнює міф і політичну ідеологію, "ніщо не нагадує так міфологію, як політична ідеологія" [11]. Для Р. Барта міф - це засіб здійснення ідеології. Міф тримається на вірі, ілюзії, а не раціональних аргументах. Для того, аби міф реалізувався, хтось має підсилити його вірою, повірити в диво, наділити думку емоцією, аби вона звучала помітніше.

Згідно з експертною оцінкою А. Цуладзе [13], "політична міфологія" є прикладною міфологією, яка завжди намагається стати реальністю. Це інтенційна міфологія, тобто така, що спрямована на конкретну групу людей 
або адресована конкретному реципієнту. А. Цуладзе виокремлює "технологічні" та "вічні"/архаїчні "міфи". "Технологічні" - це сучасні міфи, які створюються штучно, а "архаїчні" - це міфи, які передаються нам у спадок від попередніх поколінь.

За А. Цуладзе "політичний міф" - це завжди "насилля над реальністю", адже такі міфи спотворюють реальність. Таким екзистенційно трагічним прикладом "насилля міфу над реальністю" є "холодна війна", яка породила викривлене сприйняття реальності в росіян і характеризується небажанням мас миритися із істинним станом подій. Це і $€$ першопричиною появи таких необхідних "перемог", які не завойовуються, а штучно створюються. Тобто призначення таких міфів створити ефект солідарності мас. Відповідно, поширеність таких "політичних міфрів" спричинена роботою ЗМІ, які створюють "інформаційні ін'єкції", що тиражують штучні "перемоги" та посилюють їхній "успіх".

А. Цуладзе пояснює таку схильність до штучних "перемог" неготовністю до реальних жертв. А такі "символічні" війни та перемоги досягають своєї мети, поширюючись у ЗМІ і ґрунтуючись на сумнівних даних, а саме - "конспірологічних теоріях" на кшталт "світової антиросійської змови" [11, с. 3]. Така політична "гра" на мапі світу призводить до ізоляції, а неготовність діяти за визначеними правилами світового порядку спричинює заморожений конфллікт. Спочатку це "конфлікт інтерпретацій", а згодом і "конфлікт воєнний" та різного типу гібридні протистояння. Безперечно, така політична стратегія не містить жодних раціональних підвалин, а подекуди і протистоїть "здоровому глузду". Водночас усе має свої першопричини. Чим зумовлений запит саме на такі "політичні міфри"? А. Цуладзе вказує, що глибинні першопричини такого запиту укорінені в ментальному стані суспільної свідомості росіян, які не дозволяють прорватися їм в "осьовий час". До речі, Ю. Шайгородський [14] також вказує на зв'язок менталітету і появи відповідних міфів. А. Цуладзе вважає, що Росії варто покласти край "імперським міфам" і здійснити перехід від осьового до історичного часу [11]. Відповідно, однією з найефективніших міфологічних конструкцій є "теорія змови" (conspiracy theory), яка є зручним і перевіреним засобом для досягнення політичних цілей. Схема, за якою будується "теорія змови", проста й ефективна. Вона охоче сприймається, оскільки створює цілісну й несуперечливу картину світу. "Теорія змови" мовить через посередництво "лиходіїв-жертви", протистоїть ворогам, несправедливості, $€$ "миротворчою". Спростувати "теорію змови" раціональними методами майже неможливо, оскільки вона будується на недоведених, а відповідно, неспростовних аксіомах [11, с. 100]. А. Цуладзе вважає, що в сучасному світі міф почувається дуже "затишно", оскільки з приходом "галактики Гутенберга" роль 3МІ і телеіндустрії набула глобальних масштабів, тобто ЗМІ формують суспільну думку, маніпулюють, розставляючи "хиткі" і "заангажовані" акценти в поданій інформації. Насправді телебачення не передбачає зворотнього зв'язку, воно дає готовий медіапродукт, який можна лише споживати, але неможливо якісно "перетравити". Як наслідок, це призводить до збільшення лав "сліпих" споживачів "потрібного" медіапродукту. Відповідно, боротьба за контроль і вплив на медіа є виправданою в політичних перегонах, адже більш сприятливого майданчика для висловлювання своєї "правди" важко віднайти. А. Цуладзе пропонує певну техніку захисту від міфу, яка полягає або в ігноруванні політики взагалі або у спроможності зайняти визначену ідеологічну позицію [11, с. 269]. У будь-якому разі слід завжди зберігати пильність "здорового глузду" і не втрачати здатність критичного мислення. Це передбачає вміння аналізувати, порівнювати будь-які повідомлення ЗМІ, слід навчитися "читати" і "працювати" $з$ інформацією, відокремлювати фракти від їх інтерпретації. Усім 3МІ властиво драматизувати події, тому слід навчитися скептично ставитися до "сенсацій".

Суть "політичного міфу" полягає в тому, що він завжди адресується конкретній аудиторії, враховує ії "слабкі" місця, особливості менталітету. Панівну позицію у "політичному міфі" відіграє стереотип, який набуває своїх гіпербол у різних варіаціях його тиражування. Донести до реципієнта нову інформацію можна шляхом: використання вже наявних стереотипів; шляхом зміни акцентів у смисловому повідомленні, яке адресується; створенням нових стереотипів, ще більш емоційно забарвлених, що пробуджують до активних дій $[11$, с. 5]. Будь-який стереотип формується на узагальненнях. Стереотипи формуються як стихійно, так і штучно. У чому ж полягає різниця між стереотипами і міфами? "Стереотип - це певний ярлик", який клішує, ранжує, який задає тональність, контекст, але в ньому немає розповіді, немає story. Тобто стереотип $€$ формою, а міф $є$ змістом, історією. Найбільш ефрективним стереотипом є той, що працює з емоціями. Досліджуючи питання міфу, А. Цуладзе доходить висновку, що вся публічна політика будується переважно на емоціях. Можемо пригадати промови найвідоміших політиків і політичних лідерів, більшість яких сконструйована на емоціях і апелює до пробудження необхідних настроїв у електорату. Переважно використовується апеляція до базових людських потреб, страху перед невизначеністю, почуття обов'язку і справедливості, почуття провини. Це $є$ апеляцією, навіть не так до емоцій, як до самих інстинктів, природних нахилів людини. Оскільки "лікувати" суспільство важко і дорого, то "імітація" лікування суспільства $€$ прийнятним варіантом для політиків [11]. Така "імітація" роботи із суспільством є "політичною магією". До речі, Е. Фромм у роботі "Здорове суспільство" пише про "історію хвороби" сучасного суспільства, причину якого вбачає у всеосяжному та неконтрольованому споживанні речей, товарів, людських стосунків. А. Цуладзе переконливо доводить, що "політичний міф" завжди створюється штучно з відповідною політичною метою.

Якими ж є основні знаряддя маніпуляцій політичного міфу? 3 чого складається "тіло" політичного міфу? 3 механізму "свій - чужий", протистояння "добра - зла", "правди - кривди", "лиходіїв - жертв", "героя - кривдника", "героя - антигероя", "білого - чорного". Міф завжди має свого героя, який кидає виклик і захищає свою "правду". Міф характеризується емоційним переживанням, а не критичним сприйняттям історичного матеріалу. Міф має ірраціональні підвалини та керує емоціями за допомогою стереотипів. Міф створює свою реальність та створює ефект солідарності мас.

Як протистояти "магічному" впливу політичного міфу? Міф нічого не пояснює, а створює ефект дива. Для того щоб захиститись від міфу, слід пам'ятати, що слова не тотожні реальності. Протистояти міфу можна завдяки розвитку критичного мислення засобом широкої просвіти мас, появі незаангажованих $3 \mathrm{MI}$, що сприятиме розвитку аналітичного мислення, а не "сліпому" його споживанню. У свою чергу, ми не можемо вимагати від мас неможливого, очевидно, що аналітичне мислення і здатність критичного судження не притаманні масової свідомості.

Відповідно, міфи були, $є$ і залишаються найефективнішим знаряддям політтехнологів задля досягнення відповідних політичних цілей. Міф дозволяє здійснити розподіл сил на свою користь, досягти перерозподілу 
владних повноважень та отримати доступ до нових владних ресурсів. Міф розповідає свою "заангажовану" історію і шукає своїх глядачів. Чому глядачів? Тому що політичний міф є театральним, драматичним за своєю суттю. Пригадаємо Р. Барта [2], який казав, що міф послуговується театральною вимовою, магічною тавтологією і афористичністю. Звідси, він визначає ідеологізацію як "магічний тип поведінки". До речі, Р. Барт вважав, що ліві сили (ті партії, що стоять на ідеалах соціальної рівності, як соціал-демократичні та ліволіберальні партії) недостатньо опанували таке політичне знаряддя, як міф, не навчились настільки драматично вживатися у роль, будь-які інтенції міфу з вуст лівих сил видаються штучними, в них занадто "відчувається присмак гасла" [2]. Найбільш переконливим міфом $є$ міф, виголошений 3 вуст людини, яка $€$ поборником ідей справедливості і рівності всіх і кожного. До речі, цю ідею всеосяжної справедливості було досить гостро розкритиковано Г. Лебоном [5]. Г. Лебон (1841-1931) французький психолог, антрополог, історик, якому належать такі слова: "Людство постійно з розпачем чіпляється за мертві ідеї і мертвих богів", а найкращі представники розуму націй замість говорити "гірку" правду, переконують маси в нісенітницях, однією з яких $\epsilon$ ідея рівності. Г.Лебон твердить, що маси підхопили ідею рівності і прийшли до віроломного і досить легковажного висновку про те, що нерівність $€$ наслідком відмінностей у вихованні, що всі люди народжуються розумними і добрими. Відповідно, засобом боротьби проти нерівності $€$ перебудова інституцій, які дозволили б усім формуватися в однакових умовах і мати рівні можливості. До речі, "Психологію народів і мас" було написано Г. Лебоном у 1895 році, а ідея рівності і сьогодні досягається такими самими засобами і виявляється у вигляді уніфікованої системи права, дотриманні прав і свобод людини, забезпеченні соціальних гарантій громадянина. Відповідно, досягається завдяки злагодженій роботі державних інституцій. У цьому аспекті базових принципів і головно соціальних цінностей і функціонують "Amnesty International", "Venice Commission", мета останньої - впровадження демократії через право, що досягається завдяки впровадженню уніфікованої системи міжнародного права засобом таких критеріїв, як приведення регіональних державних інституцій до високих стандартів європейського порядку.

Г. Лебон палко заперечує ідею рівності всіх і кожного і називає такі політичні проекти великою оманою. Відповідно, уніфікованість інституцій і всеосяжність просвіти, які стали панацеєю для здійснення демократичних перетворень, за оцінкою Г. Лебона, є ілюзією 3 непередбачуваними наслідками. Засобом просвіти й інституцій неможливо втілити ідею рівності. Дослідник переконаний, що такими засобами не можна виправити і змінити подекуди несправедливі закони природи. Останні $€$ незмінними і не переписуються людьми. Г.Лебон вважає, що це $є$ химерою. Єдине джерело важливих змін, які є першопричиною оновлення цивілізацій і націй, міститься в ідеях, поняттях, віруваннях [5].

Таким чином, "політичний міф" - це штучно сконструйована в лабораторних умовах історія, що у спрощеній формі пояснює світ, ґрунтуючись на принципах: "герой - антигерой" тощо. У міфі відсутня поліваріантність, немає смислових відтінків, є тільки "біле (своя правда) і чорне", отже, міф - це спроба створити цілісну картину світу обмеженими засобами. Міф завжди підсилений емоціями, схильний до драматизації і театрального дійства. Міф потребує, аби його герой повністю вживався в необхідний образ чи то "героя", чи то "борця" за справедливість. Міф не розповідають, міфом живуть.
Міф - це ілюзія бажаного, це обіцянка кращого без активних дій. Міф створює ілюзію "дива", ілюзію рівності розподілу земних благ і історичних завоювань, міфр спотворює історичну картину одноосібними перемогами, міф почасти фральсифікує історію.

Попередньо ми вже згадували смислову інтенцію, що належить нашому колезі Ю. Шайгородському [14], смисл якої полягає у прямому зв'язку притаманного суспільству менталітету і появи відповідних міфів, тобто йдеться про специфіку прочитання міфу, враховуючи особливості менталітету певної нації. Спробуємо проілюструвати такий специфрічний спосіб прочитання міфу у вітчизняних "польових" умовах. Дуже часто з вуст відомих політиків звучить інтенція "Сингапурського дива", що породжує міф швидкого реформування. Звернемо увагу, що в таких голослівних промовах спостерігається пряме ототожнення реформ і дива. Ми як дослідники маємо бути послідовними і вивчати першопричини. Відповідно, будувати свою структуру аргументації на фрактах. Тому ми звернулись до першоджерела Лі Куан Ю "Із третього світу - в перший. Історія Сингапуру (19652000)" [7], наприкінці якого Лі Куан Ю зізнається, що такий прискорений економічний розвиток і індустріалізацію вдалося втілити в життя завдяки плануванню [7, с. 159]. Це була планова, цілеспрямована державницька політика, а не політика "дива". Сингапур - це приклад оновлення країни завдяки поєднанню "патріотизму, прагматизму і творчої практики над ідеологічними концепціями" [7, с. 5]. Недостатність ресурсів мала компенсуватися перевагою в інтелекті, дисципліні і винахідливості. Такий підхід дозволив досягнути небачених економічних вершин, зокрема, в 1959 р., коли Лі Куан Ю став прем'єр-міністром держави, ВВП на душу населення становило всього 400 дол., а вже в 1990 р. ВВП сягнуло позначки у 12200 дол., а в 1999 р. ВВП становило вже 22 тис. дол. Сьогодні Сингапур є лідером у галузі високих технологій у південно-східній Азії і центром науки. Починався такий шлях із політичних цілей, а саме: досягнення міжнародного визнання незалежності Сингапуру, організації оборонного комплексу держави і нарощення "м'язів" економіки. Від проблеми створення робочих місць, розвитку дрібного і малого підприємництва в ім'я виживання Сингапур пройшов шлях до індустріалізації, створення промисловості і виборов статус мекки високих технологій. Цього вдалося досягти завдяки сприятливому інвестиційному клімату та приходу американських транснаціональних компаній [7, с. 138]. Плацдармом таких змін був людський капітал і "чесний і компетентний уряд" [7, с. 141]. Уряд створював інфраструктуру, виділяв кошти для розвитку промисловості, мінімізував фріскальне навантаження, розробив систему спеціальних сертифікатів, що давали право строком на п'ять років бути звільненим від фіскальних відрахувань. Із країни сировинного придатку Сингапур здійснив перехід до високотехнологічного виробництва (наприклад, ліків). На момент 1997 р. в Сингапурі працювало понад 200 американських компаній [7, с. 154].

Таким чином, розумна макроекономічна політика поряд зі сприятливими умовами для приватного підприємництва, а також амбітна мета провести індустріалізацію і досягти рівня високотехнологічного виробництва аж ніяк не були "дивом", а стали наслідком титанічної, цілеспрямованої і планової діяльності усієї країни. Міф, навпаки, ніколи не говорить відверто про механізм виконання конкретних завдань, міф не говорить правду про те, що треба багато працювати, він заспокоює i обіцяє диво-ефект уже завтра. Він робить людей пасивними у процесах мислення, але активними учасниками у вирі чужих інтересів, міф завжди маніпулює. 
Це підводить нас до питання, чи втілилися ідеали Просвітництва про всеосяжність людського розуму в дійсність. Є різні погляди на це питання. Наприклад, Е. Касірер [4] вважає, що дійсність характеризується лише номінальним встановленням раціональних структур. Поява політичних і соціальних структур не тотожна зникненню міфологічної структури сприйняття. Політика - це "динамічна рівновага", у політиці все доволі змінне і відносне, але єдино принциповим і незмінним у політиці є "воля до влади" (Ф. Ніцше): "Міф завжди поруч із нами і очікує свого часу" [4, с. 580]. За оцінкою Е. Касірера, міфи не виникають стихійно, а лише цілеспрямовано, вони є штучними утвореннями [4, с. 581]. Е. Касірер, так само як і Р. Барт, ключову роль у міфрі відводить мові, точніше, слову, яке має два рівня використання. Слово може мати як семантичний, так і магічний вплив, причому магічний завжди домінує над семантичною функцією слова [4, с. 582]. Е. Касірер наводить дуже цікавий приклад такого "жонглювання" поняттями, зокрема два німецьких слова, які $€$ однокореневими, але містять суттєвий смисловий акцент, який видозмінює контекст їх сприйняття. $€$ слово "Siegfriede" (мир через перемогу Німеччини) та "Siegerfriede" (мир, умови якого будуть диктуватися ворогами Німеччини). "Люди, які створили ці слова, були справжніми майстрами мистецтва політичної пропаганди" [4, с. 583].

Таким чином, Е. Касірер, А. Цуладзе, Р. Барт вважають, що міф неможливо зруйнувати засобом раціональних аргументів, міф приймається на віру, підсилюється емоційною драматизацією, відповідно, його не можна спростовувати за допомогою силогізмів. Роль фрілософрії полягає у тому, що вона "дозволяє нам зрозуміти супротивника. Щоби перемогти ворога, ми маємо знати його це $\epsilon$ одним із принципів правильної стратегії" [4, с. 586]. Єдине, проти чого застерігає Е. Касірер - це від легковажного ставлення до міфів, "зрозуміти міфр означає зрозуміти не лише його слабкі місця, але й усвідомити його силу", силу його впливу. Відповідно, сприймати міфи як абсурдні і комічні $€$ великою оманою.

Такий скепсис щодо раціональності зберігають М. Едельман [16] і О. Аузан [1]. Найбільш репрезентативної сфрерою ірраціонального і $є$ політика. Зокрема, М. Едельман стверджує, що кількість інфрормації не тотожна її якісному сприйняттю, раціональних фрактів у політиці немає. Тобто М. Едельман, як і більшість науковців, стверджує, що ми - люди - лише номінально вважаємо, що все в житті відбувається згідно з раціональністю і логічною послідовністю [16]. Близькими є і погляди О. Аузана, який проголошує, що Просвітницьке уявлення про необмеженість раціональних людських здатностей спростовується життєвим досвідом кожного з нас. Насправді ми маємо справу з обмеженою раціональністю, "людина проти раціональності" [1, с. 10]. Порядок тримається на правилах і інституціях. М. Едельман стверджує, що політика є політичним спектаклем, ми маємо справу з заангажованими інтерпретаціями, що обумовлені політичними інтересами і ідеологіями. Головна книга М Едельмана називається "Конструкція політичного спектаклю" [16], у ній ідеться про амбівалентність політичних новин, політичну мову і політичну реальність, політичне видовище як тактику і містифікацію [16].

Ураховуючи той факт, що гасло Просвітництва, сорормульоване І. Кантом, "Sapere aude!" (з лат. "май мужність послуговуватись власним розумом"), що знаменував собою непохитну віру в силу людського розуму, $є$ досить відносним. І. Кант досить метафрорично називав неготовність послуговуватись власним розумом "неповноліттям", у сучасному світі люди схильні користуватись або прагматичним розрахунком і адаптуватися, або зберігати режим "економії мислення", що призводить до самовільної відмови послуговуватись власним розумом. Якщо $є$ стільки "зручних" інтерпретацій, навіщо докладати зусиль, щоб думати? Саме міф і дає таку спрощену "картину світу", де все $€$ самоочевидним і не потребує ані доведень, ані спростувань і приймається на віру. Лінощі розуму, споживацьке ставлення до себе і світу, неготовність прийняти не лише блага свободи, але й відповідальність призвели до стійкого ефекту маніпуляцій у політиці. Як наслідок, "ярмарка обіцянок" призводить до "інфрляції реальних справ".

Безперечно, міф не просто деформує реальність, а намагається досягнути своїх цілей засобом впливу на масову свідомість, що пов'язано з навіюванням. Відповідно, для того, аби більш ефективно конструювати міфи, слід ознайомитись з основами психоаналізу, постулатом якого $є$ безсвідоме, яке формує нашу реальність. Зокрема, В. Щербаков [15], досліджуючи питання міфру в психоаналізі, стверджує, що міф для 3. Фрейда був підґрунттям вивчення латентних механізмів культурної поведінки людини. Міф є джерелом вивчення як індивідуальної психіки, так і вказує на "історію хвороби" людини соціальної. Міф завжди є амбівалентним, сконструйованим з "добра і зла", "любові і ненависті", "страждань і насолоди", "доступності і заборони" [15]. Мiф $€$ інструментом самопізнання людини, міф веде історію від формування генетичної пам'яті до появи людини культурної. В історичній перспективі міфу 3. Фрейд знаходить структурні компоненти в контекстах: долі (Ананке), інцесту (Едіп), любові (Ерос), смерті (Ізіда і Танатос), нарцисизму (Нарцис), самопізнання (Аполон) [15]. Міф - це "ключ" до вивчення "історії хвороби" людини, у тому числі патологій, він приховує глибинні причини тих чи інших похідних дій людини "соціального світу". У психіатрії $є$ два способи прочитання досвіду минулого, перший з яких - гіпнотичний, а другий - психоаналітичний, 3. Фрейд іменує перший з них "косметичним", а другий - "хірургічним" [12]. Власне, політичний міф - це "декорація" життя, яке не є самим життям. Прочитання міфу вимагає застосування таких "хірургічних" методів, як аналітичний підхід та сміливість критичного мислення.

Ураховуючи те, що ми живемо в постінформаційну добу і маємо доступ до різних джерел інформації, чисельних даних і фактів, які дозволяють сформувати свою, обґрунтовану точку зору, це сприяє зменшенню терміну придатності політичних міфів. Водночас у межах цього дослідження нам вдалося проілюструвати, наскільки актуальною й ефективною $є$ міфологічна конструкція і в яких сферах вона працює. Політичний міф не апелює до розуму, лише до емоцій, до інстинктів, до базових потреб людини. Кожен із таких сучасних міфів створюється 3 конкретною метою, міфи завжди пояснюють світ, спрощуючи його, міфи втішають і причаровують "магічним ефектом", вони покликані роз'єднувати або, навпаки створювати ефект солідарності мас. "Воля до влади" і $є$ тією ключовою метою створення сучасних міфрів, яка виправдовує усі засоби її досягнення. Найефективнішим серед яких і $€$ міф.

Список використаної літератури

1. Аузан А. Экономика всего. Как институты определяют нашу жизнь / А. Аузан. - М. : "Манн, Иванов и Фербер", 2014. -160 с.

2. Барт Р. Миф сегодня [Электонный ресурс] / Р. Барт // Избранные работы: Семиотика. Поэтика. - М. : "Прогресс", "Универс", 1994. C. 72-130. - Режим доступа : http://lib.ru/CULTURE/BART/barthes.txt_ with-big-pictures.html.

3. Березовська-Чміль О. Б. Вплив політичних міфів на формування індивідуальної свідомості / О. Б. Березовська-Чміль, Т. В. Черниш // Наук. вісн. Рівн. гум. ун-ту. - 2013. - Вип. № 11 
4. Кассирер Э. Техника современных политических мифов / Э. Кассирер // Вестн. МГУ. Сер. 7, Философия. - 1990. - № 2. -С. 58-65.

5. Лебон Г. Психология народов и масс [Электронный ресурс] / Г. Лебон. - СПб., 1995. - Режим доступа : http://lib.ru/POLITOLOG/LEBON/ psihologia.txt.

6. Левенець Ю. Роль національного міфу у відродженні національної свідомості українського народу / Ю. Левенец // Нова політика. 2001. - № 2. - С. 50-54.

7. Ли Куан Ю. Из третього мира - в первый. История Сингапура (1965-2000) / Ю. Ли Куан. - М. : "Манн, Иванов и Фербер", 2015. - 576 с.

8. Лосев А. Диалектика мифа [Электронный ресурс] / А. Лосев.М. : "Правда", 1990. - Режим доступа : http://www.psylib.org.ua/books/l osew03/index.htm.

9. Мадрига Д. О. Політичний міф: сутність та особливості впливу на електоральний вибір / Д. О. Мадрига // Гілея: наук. вісн. : зб. наук. пр. - 2004. - Вип. 42 (№ 12). - С. 601-606.

10. Матвієнків С. Вплив політичних міфрів на свідомість молоді в сучасній Україні / С. Матвієнків, В. Штерн // Вісн. Львів. ун-ту. Серія філос.-політолог. студії. - 2014. - Вип. № 5. - С. 72-78.

11. Сурков А. Миф, сила и насилие в философии Ж. Сореля [Электронный ресурс] / А. Сурков. - М., 2013. - Режим доступа http://www.runivers.ru/philosophy/logosphere/471679/. 1917

12. Фрейд 3. Введение в психоанализ : лекции / 3. Фрейд. - СПб.,

13. Цуладзе А. Политическая міфологія [Электронный ресурс] 3. Фрейд. - М. : ЭКСМО, 2003. - 383 с. - Режим доступа http://docslide.us/documents/-54683c79b4af9f3a6d8b4b4d.html.

14. Шайгородський Ю. Політичний міф як інструмент дослідження політики / Ю. Шайгородский // Сучасна українська політика. - 2010. Вип. № 21. - С. 32-38.

15. Щербаков В. Миф в психоанализе : Сборник в честь 90-летия профессора М. И. Шахновича [Электронный ресурс] / В. Щербаков. СПб. : Санкт-Петербургское фрилософское общество, 2001. Серия "Мыслители", Смысли мифа: мифология в истории и культуре. Вып. 8. - Режим доступа : http://anthropology.ru/ru/text/shcherbakov-vp/mif-vpsihoanalize.

16. Edelman M. Constructing the Political Spectacle / M. Edelman. Chicago : University of Chicago Press, 1988. - $142 \mathrm{p}$

17. Tudor H. Political Myth (Key Concepts in Political Science) / H. Tudor. - London, 1973. - $160 p$

\section{References:}

1. Auzan, A. Ekonomyka vsego. Kak instytuty opredelyajut nashu jyzn (The economy of everything. How Institutions Define Our Lives). M., "Mann, Ivanov i Ferber", 2014. $160 \mathrm{~s}$

2. Bart, R. Mif segodnya (Myth today). Izbrannye raboty: Semiotika. Poetika. M., "Progress", "Univers", 1994. S. 72-130, available at: http://lib.ru/CULTURE/BART/barthes.txt_with-big-pictures.html.
3. Berezovska-Chmil, O.B., Chernish. T.V. Vplyv politichnych mifiv na formuvannja indivydualnoji svydomosti (The influence of political myths on the formation of individual consciousness) // Naukovij visnyk Rivnenskogo derjavnogo gumanitarnogo universytetu. 2013, Vyp. № 11

4. Kassirer, E. Technyka sovremennych politicheskich mifov (Technique of modern political myths). Vestnik MGU. Seriya 7, Filosofiya. 1990, № 2. P. 58-65.

5. Lebon G. Psychologia narodov i mass (Psychology of peoples and masses). - SPb. 1995. available at: http://lib.ru/POLITOLOG/LEBON/ psihologia.txt.

6. Levenets, Y. Role nazionalnogo mifu u vidrodjenny nationalnoji svydomosti ukrainskogo narodu (The role of national myth in the revival of the national consciousness of the Ukrainian people). Nova politika. 2001, № 2. S. 50-54.

7. Li Kuan, Yu. Iz tretyego myra - v pervij. Istoriya Singapura (19652000) (From the third world to the first. History of Singapore (1965-2000)). M., "Mann, Ivanov i Ferber", 2015. 576 s.

8. Losev, A. Dialektyka mifa (Dialectic of myth). M., "Pravda", 1990. available at: http://www.psylib.org.ua/books/losew03/index.htm.

9. Madryga, D.O. Polytychnij mif: sutnyist ta osoblyvosty vplyvu na elektoralnyi vybyr (Political myth: the essence and features of influencing electoral choice). Gileya: nauk. visn. : zb. nauk. pr. 2004, Vip. 42 (№ 12). C. 601-606.

10. Matvienkiv, S., Schtern, V. Vplyv politychnych mifiv na svydomyst molodi $v$ suchasnij Ukraini (The influence of political myths on the minds of young people in modern Ukraine) Vysnyk Lvivskogo universytetu. Seria filos.-politolog.studiy. Vyp. № 5., 2014. S. 72-78.

11. Surkov A. Mif, syla i nasyliye $v$ filosofiji J. Sorelya (Myth, power and violence in philosophy). M., 2013, available at: http://www.runivers.ru/ philosophy/logosphere/471679/.

12. Freyd Z. Vvedeniye $v$ psychoanaliz (Introduction to psychoanalysis: lectures). SPb., 1917

13. Zuladze, A. Polytycheskaja mifologiya (Political mythology). M., "EKSMO". 2003. $383 \mathrm{~s}$

14. Shajgorodskyi, Y. Polytychnyj mif yak instrument doslidjennya polityky (Political myth as a tool for policy research). Suchasna ukrainska polityka. 2010, Vyp. № 21. S. 32-38.

15. Scherbakov, V. Mif $v$ psychoanalyze (Myth in psychoanalysis). SPb., Sankt-Peterburgskoe filosofskoe obshchestvo, 2001. Seriya "Myslyteli", Smysly mifa: mifologia v istoryij i culture. 2001, Vyp. 8, available at: http://anthropology.ru/ru/text/shcherbakov-vp/mif-v-psihoanalize.

16. Edelman, M. Constructing the Political Spectacle. Chicago, University of Chicago Press, 1988. $142 \mathrm{p}$

17. Tudor, H. Political Myth (Key Concepts in Political Science). London,1973. 160 p.

Надійшла до редколегії 15.03.21

В. Ю. Омельченко, канд. филос. наук, ассист.

Киевский национальный университет имени Тараса Шевченко, Киев, Украина

\section{К ВОПРОСУ О СОВРЕМЕННЫХ МИФАХ.}

\section{"ПОЛИТИЧЕСКИЙ МИФ" КАК ПРИКЛАДНАЯ МИФОЛОГИЯ}

Посвящено исследованию понятия "мифа" и выявлению сущностных признаков понятия "политического мифа", осмыслению вопроса, чем является "политический миф" сегодня, на каком языке он говорит, к чему апеллирует. В рамках данного исследования доказано, что "политический миф" является коммуникативной системой, которая деформирует реальность. Установлено, что каждый "политический миф" имеет свой срок годности и пределы своей интерпретации. Подтверждено, что "политический миф" является одним из самых эффективных инструментов для реализации таких политических целей, как достижение власти и её легитимация. Благодаря исследованию специфических признаков "политического мифа" удалось установить, что политический дискурс является иррациональным, а политические речи апеллируют к аргументу чувственного, а не рационального начала. "Политический миф" моделирует свою "картину мира", которая является упрощенной и самоочевидной. Обосновано, что способность критического суждения, умение работать с информацией и качественная аналитика, работа незаангажированных СМИ и экспертной среды, хотя и не является панацеей, но все же частично нивелируют "силу" влияния "политического мифа". Особое внимание в данном исследовании посвящено таким понятиям, как "политическая магия" и "политический спектакль" в контексте "политической мифологии" как прикладной мифологии.

Ключевые слова: миф, политический миф, политтехнологии, электорат, политические цели, "теория заговора", "политическая магия", "политический спектакль".

Victoria Omelchenko, PhD of Philosophical Science, Assist.

Taras Shevchenko National University of Kyiv, Kyiv, Ukraine

\section{ON THE QUESTION OF MODERN MYTHS. POLITICAL MYTH AS APPLIED MYTHOLOGY}

In this article, the author argues that philosophy is a "methodology" of understanding. Hermeneutics is the theory and methodology of interpretation especially the interpretation philosophical texts. H.-G. Gadamer asserted that methodical contemplation is opposite to experience and reflection. We can reach the truth only by understanding or mastering our experience. According to H.-G. Gadamer, our understanding is not fixed but rather is changing and always indicating new perspectives. The most important thing is to unfold the nature of individual understanding. Hermeneutics is not just "art", but the methodology of "understanding." Accordingly, philosophy is the methodology of understanding and interpretation. Philosophy is a science with its own subject and object. Legal laws are not absolute, therefore they should be interpreted. It is the task of philosophy. Philosophy speaks the language of concepts and evidence. Concepts should be specific, clear, defined. Philosophical work is the formulation of concepts. On the basis of such understanding of philosophy, we will now study the question of "political myth".

Scientific exploration is devoted to the study of the concept of "myth" and identifying the essential features of the "political myth". What is "political myth" of modernity? What language is he speaking? What appealed? In this intelligence proved that "political myth" is a communication system that distorts reality. It is established that every "political myth" has its own shelf life and the boundaries of its interpretation. It is confirmed that "political myth" is one of the most effective tools to meet political goals, such as achievement of power and its legitimation. It is proved that political discourse is irrational, and political speeches appeal to the argument of sensuous, not rational. "Political myth" models own "world picture", which is a simplified, taken for granted, self-evident. It is proved that the ability of critical judgment, ability to work with information and quali- 
tative analysis from the mouth of the unbiased media and the expert environment, though not a panacea, but partially negate the "force," "political myth". Myth has an irrational basis, and controls the emotions with the help of stereotypes. The myth creates its own reality and creates the effect of solidarity of the masses. The essence of "political myth" is that he always addressed to specific audiences, takes into account the peculiarities of mentality. A dominant position in the "political myth" plays a stereotype. Any stereotype is formed on the generalizations. What is the difference between the stereotypes and myths? "A stereotype is a label", which is the context, but it there is no story. That is, the stereotype is a form, and the myth is content history. In addition, in this exploration of the role and value of such concepts as "political magic" and "political spectacle" in the context of "political mythology" as applied mythology.

Keywords: myth, political myth, political strategies, constituency, political aims, "conspiracy theory", "political magic", "political spectacle".

UDC 141.319.8

DOI: 10.17721/sophia.2021.17.10

Vitalii Turenko, PhD, Research Assist.

Taras Shevchenko National University of Kyiv, Kyiv, Ukraine ORCID: 0000-0003-0572-9119

e-mail: vitali_turenko@ukr.net

Vasyl Semykras, PhD, Assoc. Prof.

Taras Shevchenko National University of Kyiv, Kyiv, Ukraine ORCID: 0000-0002-5125-5172

e-mail: semvv@ukr.net

\section{PHILOSOPHICAL LEGACY OF V. G. TABACHKOVSKYI: HISTORICAL AND PHILOSOPHICAL RECONSTRUCTION}

Purpose of this article is consists in the complex researche of the many-sidedness of the philosophical legacy of the famous Ukrainian philosopher of the second half of the XXth century, one of the founders of philosophical anthropology in Ukraine Vitalii Tabachkovskyi (1944-2006). The theoretical and methodological basis of the study is historical and philosophical reconstruction. A number of concepts and conclusions were applied, which take place in the context of the scientific works of Ukrianian authors on this issue. The author reveals the transformation of Vitalii Tabachkovsky's scientific research during the Soviet period and revealed the specificity and its significance of legacy in the context of Ukrainian philosophical thought of the second half of the twentieth century. Revealed that at the intersection of the 60s and 70s. The twentieth century in the center of attention of $V$. Tabachkovsky was the problem of the relationship between personal and impersonal, as a result of which her thorough research was the first that critically interpreted the key philosophical and anthropological problems of French personalizm. It was revealed that, on the basis of the then official philosophy, the practice phenomenon occupied a significant place, which became a key subject of research for Vitalii Tabachkovsky in the 1970s and until the mid-1980s. The peculiarity of his explication was that the practice was not only epistemological content (in the spirit of the ideology of Marxism-Leninism), but also related to the inner world of man. It was found that in the era of Perestroika and with the proclamation of independence of Ukraine, the scientific interests of V. Tabachkovsky focused on understanding the human perception of the world, alienation, as well as essential and existential in human nature. The practical significance of the study lies in the possibility and necessity of using its results in the context of complex and systematic studies of the history of Ukrainian philosophy in the Soviet period.

Keywords: philosophical thought of the Soviet Ukraine, Vitalii Tabachkovskyi, philosophical anthropology, practice.

\section{Introduction}

Research of the legacy of Ukrainian philosophers of the second half of the twentieth century is still a poorly developed topic. The urgency of comprehensive studies of the key representatives of this period in the history of Ukrainian philosophy is due to a number of reasons, namely: a biased view of the Ukrainian philosophy of the Soviet period, the predominance of an essayistic, memoiristic character of the works of researchers on this period. Thus, the expediency of a comprehensive and systematic of the scientific legacy of Ukrainian thinkers of the second half of the twentieth century appears, among which of them Vitalii G. Tabachkovskyi is one of the leading figure.

\section{Sources}

Scientific inquiries devoted to the personality of $\mathrm{V}$. Tabachkovskyi and the main problems, which he studied were presented by the articles of $\mathrm{Y}$. Andros [1], A. and I. Bychko [2], S. Vilchinska [3], A. Danylyuk [5], V. Darensky [6], V. Ryzhko [9]. At the same time, special attention should be paid to the work of A. Zaluzhna [7], which analysis the peculiarity of the exploration by the domestic Soviet philosophers of the spiritual and moral issues of a person in the conditions of the dialectical materialism's paradigm.

However, we can say that at present in the scientific literature there are no systematic studies devoted to V. Tabachkovskyi, which would show the transformation of his research interests, as well as the specifics of his philosophical legacy during the Soviet period.

\section{Methodology}

The theoretical and methodological basis of the study is historical and philosophical reconstruction. A number of concepts and conclusions were applied, which take place in the context of the scientific works of Ukrianian authors on this issue.

\section{Results}

Intellectual area was inherent to philosophical thought "late Soviet Marxism" $60-90$ years of the twentieth century, which showed the presence of two philosophies:

- as legalized, the official philosophy for the humanitarians of the party nomenclature, fully orientated to the state party ideology;

- the philosophy of the sixties, as the "shadow", which, in the framework of the absoluteization of the Marxist-Leninist doctrine, ensured the preservation and renewal of professional philosophy, which grew into the philosophical schools of E. Ilyenkov and A. Zinoviev, P. Kopnin and V. Shynkaruk $[7 ; 20]$.

Vitalyi Tabachkovskyi (1944-2006) is a Ukrainian philosopher, who began his scientific career in 1968 and was associated own his life with the NAS H. S. Skovoroda Institute of Philosophy. 